\title{
Determination of the Antiretroviral Drug Zidovudine in Diluted Alkaline Electrolyte by Adsorptive Stripping Voltammetry at the Mercury Film Electrode
}

\author{
Arnaldo Aguiar Castro ${ }^{1,2}$, Ricardo Queiroz Aucélio ${ }^{1}$, Nicolás Adrián Rey ${ }^{1}$, Eliane Monsores Miguel ${ }^{1}$, \\ Percio Augusto Mardini Farias ${ }^{1}$ \\ ${ }^{1}$ Department of Chemistry, Pontificia Universidade Católica do Rio de Janeiro, Rio de Janeiro, Brazil \\ ${ }^{2}$ Fac. Química, Química Analitica, Universidad de La Habana, Havana, Cuba \\ E-mail:pfarias@puc-rio.br \\ Received October 7, 2010; revised November 4, 2010; accepted December 28, 2010
}

\begin{abstract}
This paper describes a stripping method for the determination of zidovudine at the submicromolar concentration levels. This method is based on the controlled adsorptive accumulation of zidovudine at the thin-film mercury electrode, followed by a linear-sweep stripping voltammetry measurement of the surface species. Optimal experimental conditions include a NaOH solution of $2.0 \times 10^{-3} \mathrm{~mol} \cdot \mathrm{L}^{-1}$ (supporting electrolyte), an accumulation potential of $-0.30 \mathrm{~V}$ and a scan rate of $100 \mathrm{mV} \cdot \mathrm{s}^{-1}$. The response of zidovudine is linear over the concentration range $0.01-0.08 \mathrm{ppm}$. After an accumulation time of 5 minutes, the detection limit was found to be $0.67 \mathrm{ppb}\left(2.5 \times 10^{-9} \mathrm{~mol} \cdot \mathrm{L}^{-1}\right)$. More convenient methods to measure zidovudine concentration in the presence of the didanosine, acyclovir, nevirapine, lamivudine, and efavirenz, were also investigated. The presence of zidovudine together with ATP or ssDNA demonstrates the utility of this method.
\end{abstract}

Keywords: Zidovudine Determination, Antiviral Drugs, Ssdna, Thin-Film Mercury Electrode, Stripping Voltammetry

\section{Introduction}

Zidovudine (Figure 1) or azidothymidine (AZT) (also called ZDV), is a nucleoside analog reverse transcriptase inhibitor (NRTI), a type of antiretroviral drug. It is also sold under the names Retrovir and Retrovis, and as an ingredient in Combivir and Trizivir. It is an analog of thymidine. It was used as the first approved treatment for HIV. AZT does not destroy the HIV infection, but only delays the progression of the disease and the replication of virus, even at very high doses. During prolonged AZT treatment, HIV has the ability to increase its resistance to AZT by mutating its reverse transcriptase. In order to slow down the process of developing resistance, physiccians generally recommend that AZT be given in combination with another reverse transcriptase inhibitor and an antiretroviral from another group, such as a protease inhibitor or a non-nucleoside reverse transcriptase inhibitor [1-8].

Several methods have been discovered for the quantitative determination of zidovudine including chromatog-
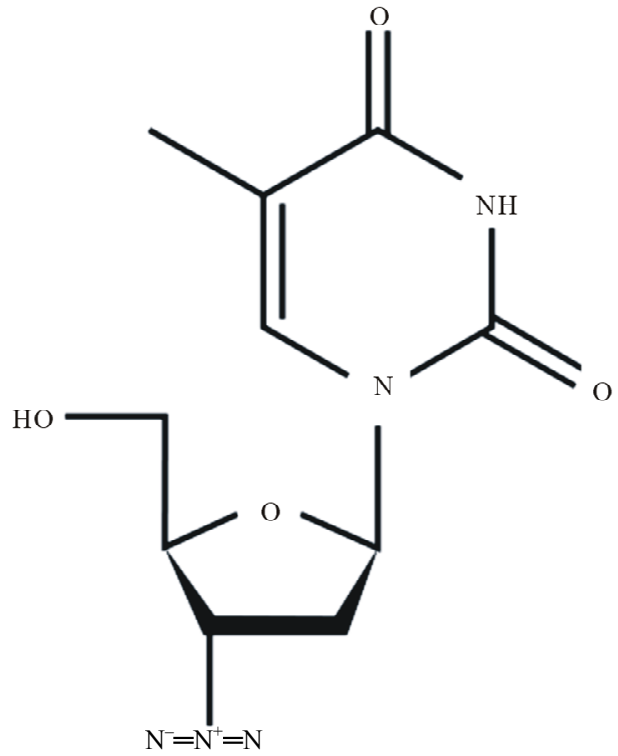

Figure 1. Structure of zidovudine (AZT); [1-[(2R,4S,5S)-4azido-5-(hydroxymethyl)oxolan-2-yl]-5-methyl-1,2,3,4-tetra hydropyrimidine-2,4-dione]. 
raphy [9-15], fluorescence polarization immunoassay [16], using diamond paste based immunosensor [17], fluorescence spectroscopy [18] and voltammetry [19-24]. With the recent advancements in properties of the adsorptive stripping voltammetry, new methodologies have been developed for adenine, thymine, guanine, ATP, and DNA determinations employing alkaline solution with lower ionic strength as the supporting electrolyte [25-28]. Using this alkaline electrolyte, the present work found a new stripping voltammetric procedure to trace the detection of zidovudine based on its adsorption at the thin film mercury electrode. The advantages, instrumental parameters, and possible limitations of this procedure will be explained in this paper. Furthermore, the effects of a wide range of potentially interfering compounds such as didanosine, acyclovir, nevirapine, lamivudine, efavirenz, some metal ions, and ATP or ssDNA are examined.

\section{Experimental}

\subsection{Apparatus}

Linear-sweep stripping voltammograms were obtained with an EG\&G PAR model 384-B Polarographic Analyser (Princeton Applied Research, Princeton, NJ, USA), equipped with an external cell and a Houston AmetekDMP-40 series digital plotter. The working electrode was a glassy carbon electrode (GCE, $3.0 \mathrm{~mm}$ diameter, BAS-Bioanalytical Systems, Inc., West Lafayette, Indiana 47906, USA) containing thin-film mercury, an Ag/ $\mathrm{AgCl}$ reference electrode with vicor tip and a platinum auxiliary electrode. A magnetic stirrer and stirring bar (Nalgene Cat. No. 6600 - 0010, Rochester, NY, USA) provided convective transport during the process of accumulation.

\subsection{Forming Thin-Film Mercury Electrode}

The thin mercury film was formed in a $10^{-2} \mathrm{~mol} \cdot \mathrm{L}^{-1}$ $\mathrm{Hg}\left(\mathrm{NO}_{3}\right)_{2}$ solution, prepared by the dissolving $0.4 \mathrm{~g}$ of mercury (II) nitrate into $100 \mathrm{~mL}$ of an acidified Milli-Q water $\left(5 \%\right.$ of $\left.\mathrm{HNO}_{3}\right)$. A glassy carbon electrode (GCE, BAS) was first polished with alumina (PK-4, BAS) and then mounted with the help of a Teflon holder in a voltammetric cell provided with an $\mathrm{Ag} / \mathrm{AgCl}$ reference electrode, a platinum auxiliary electrode, $1 \mathrm{~mL}$ of mercury (II) nitrate solution, $1 \mathrm{~mL}$ of $10^{-1} \mathrm{~mol} \cdot \mathrm{L}^{-1}$ potassium nitrate solution and $8 \mathrm{~mL}$ of purified water. The solution was purged with nitrogen for $240 \mathrm{~s}$ in order to eliminate the oxygen that was present initially. Mercury plating was carried over for $5 \mathrm{~min}$ at a cell of $-0.9 \mathrm{~V}$. After checking that the electrode was plated properly, the set of electrodes was rinsed with water and a new clean cell containing the analyte solution was fitted.

\subsection{Reagents}

Water purified in a Milli-Q purification system (Millipore, Billerica, MA, USA) was used for all dilutions and sample preparations. All chemicals were of the analytical reagent grade. Zidovudine standard was used as it was received by the FarManguinhos - FIOCRUZ (Fundação Oswaldo Cruz - RJ). Stock solutions of 1000 ppm were prepared by dissolving $50 \mathrm{mg}$ of the target reagent zidovudine into $5 \mathrm{~mL}$ of $2 \mathrm{~mol} \cdot \mathrm{L}^{-1} \mathrm{NaOH}, 5 \mathrm{~mL}$ of ethylic alcohol and water until a volume of $50 \mathrm{~mL}$ was reached. Diluted zidovudine solutions of 100 or $10 \mathrm{ppm}$ were prepared daily by dissolving $5 \mathrm{~mL}$ of 1000 or $100 \mathrm{ppm}$ zidovudine into water until a volume of $50 \mathrm{~mL}$ was reached. Stock solutions of other HIV drugs were prepared using the same procedure described for zidovudine. The didanosine and aciclovir stock solutions were prepared without using along with ethylic alcohol. A 1000 ppm copper, other metal stock solutions (atomic absorption standard solution, Sigma-Aldrich Brasil Ltda.), were used and diluted as required for standard additions. Stock solutions of $1000 \mathrm{ppm}$ of adenosine 5'-tripho- sphate and disodium salt hydrate (ATP) were prepared by dissolving $10 \mathrm{mg}$ of the target reagent into $2 \mathrm{~mL}$ of diluted perchloric acid $\left(10^{-1} \mathrm{~mol} \cdot \mathrm{L}^{-1}\right)$. The subsequent solution was heated at $70^{\circ} \mathrm{C}$ for 30 seconds. After being heated, the sample was cooled down and diluted with water to a volume of $10 \mathrm{~mL}$. Single-stranded calf thymus DNA (Cat. No. D-8899; Lot 43H67951) was used as it was received from Sigma. A $500 \mu \mathrm{g}$ DNA $/ \mathrm{mL}$ stock solution (around $5 \mathrm{mg} / 10 \mathrm{~mL}$; lyophilized powder containing $63 \%$ DNA) was prepared according to the ATP procedure. The final solution was stored at $4^{\circ} \mathrm{C}$.

\subsection{Procedure}

A known volume $(10 \mathrm{~mL})$ of the supporting electrolyte solution $\left(2.0 \times 10^{-3} \mathrm{~mol} \cdot \mathrm{L}^{-1}\right.$ sodium hydroxide (with $1 \%$ $\mathrm{v} / \mathrm{v}$ of ethylic alcohol)) was added to the voltammetric cell and degassed with nitrogen for 8 min (and for 60 seconds before each adsorptive stripping cycle). First, the condition potential (usually $-0.9 \mathrm{~V}$ ) was applied to the electrode for a set amount of time (usually $60 \mathrm{~s}$ ). Afterwards, the initial potential $(-0.30 \mathrm{~V})$ was applied to the electrode for a set amount of time (usually $90 \mathrm{~s}$ ). The solution was stirred slowly throughout this time. The stirring was then stopped, and after $30 \mathrm{~s}$, the voltammogram was recorded by applying a negative-going potential scan. The scan (at $100 \mathrm{mV} \cdot \mathrm{s}^{-1}$ ) was stopped at $-1.10 \mathrm{~V}$, and the adsorptive stripping cycle was repeated using the same thin-film mercury. After the background stripping volt- 
ammograms were obtained, aliquots of the zidovudine standards were introduced. The entire procedure was automated, as controlled by 384-B Polarographic Analyser. Throughout this operation, nitrogen was passed over the surface of the solution. All data were obtained at room temperature $\left(25^{\circ} \mathrm{C}\right)$.

\section{Results and Discussion}

\subsection{Parameters Affecting the Adsorptive Stripping Behavior}

Figure 2 compares the differential-pulse, linear-scan and linear-sweep adsorptive stripping voltammograms using $0.10 \mathrm{ppm}$ zidovudine in a $2.0 \times 10^{-3} \mathrm{~mol} \cdot \mathrm{L}^{-1} \mathrm{NaOH}$ solution (with $1 \% \mathrm{v} / \mathrm{v}$ of ethylic alcohol) after 90 seconds of preconcentration, stirring at $-0.30 \mathrm{~V}$. A mercury film was used as a work electrode. After an equilibrium time of $30 \mathrm{~s}$, the differential pulse (A) and linear (B) or cyclic cathodic voltammogram $(\mathrm{C})$ was recorded at 50 (A) and $100(\mathrm{~B}, \mathrm{C}) \mathrm{mV} \cdot \mathrm{s}^{-1}$, respectively. Both scan modes offer excellent signal-to-background characteristics. Linear scans, however, offer a higher current peak and a greater speed, and are recommended for the determination of $\mathrm{zi}^{-}$ dovudine. The linear-sweep stripping mode yields a well- defined peak, with half-width $\left(b^{1 / 2}\right)$ of $80 \mathrm{mV}$. The zidovudine cyclic cathodic peak $\left(I_{p}\right)$ appears at $-0.68 \mathrm{~V}$ $\left(E_{p}\right)$. No anodic peak was observed in the first scan.

Figure 3 shows the linear-sweep adsorptive voltammogram for $0.1 \mathrm{ppm}$ of zidovudine in a $2.0 \times 10^{-3} \mathrm{~mol} \cdot \mathrm{L}^{-1}$ $\mathrm{NaOH}$ solution (with $1 \% \mathrm{v} / \mathrm{v}$ of ethylic alcohol), using a pre-concentration time of $60 \mathrm{~s}$, while being stirred however, at -0.15 (A) and -0.30 (B) V. After an equilibrium time of $30 \mathrm{~s}$, the linear-sweep voltammogram was recorded at $100 \mathrm{mV} \cdot \mathrm{s}^{-1}$. With accumulation potential at $-0.15 \mathrm{~V}$, the zidovudine cyclic voltammogram showed two peaks at -0.28 and $-0.62 \mathrm{~V}$. Only a single, well- defined, higher cathodic peak $\left(I_{p}\right)$ with half-width $\left(b^{1 / 2}\right)$ of 80 $\mathrm{mV}$ peak appears at $-0.68 \mathrm{~V}\left(E_{p}\right)$. This occurs when the accumulation potential used was of $-0.30 \mathrm{~V}$. This accumulation potential was used throughout this study.

Other chemicals and instrumental parameters such as the supporting electrolyte, the $\mathrm{pH}$ level, the accumulation time, and the scan rate (which directly affects the zidovudine adsorptive stripping peak response) were also optimized. The adsorption properties of the zidovudine vary depending on the composition of the supporting electrolyte. Various electrolytes, e.g. Briton-Robinson,

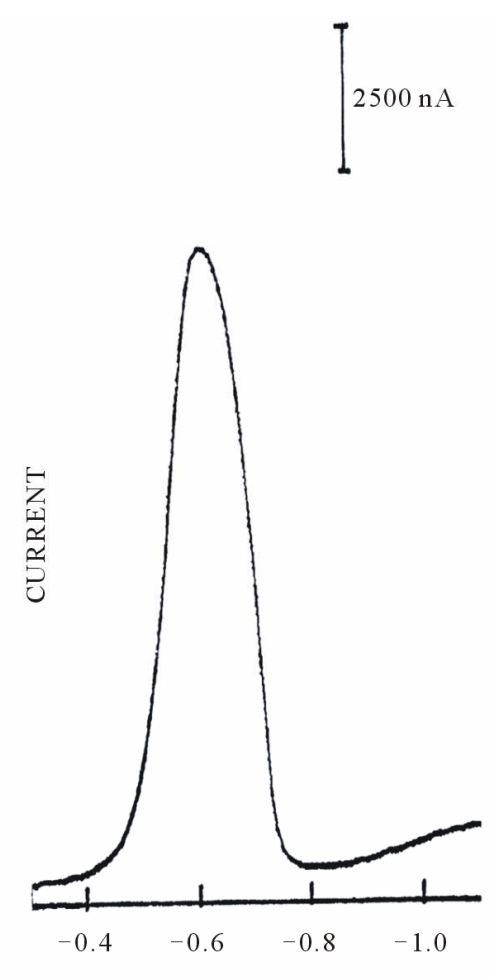

(a)

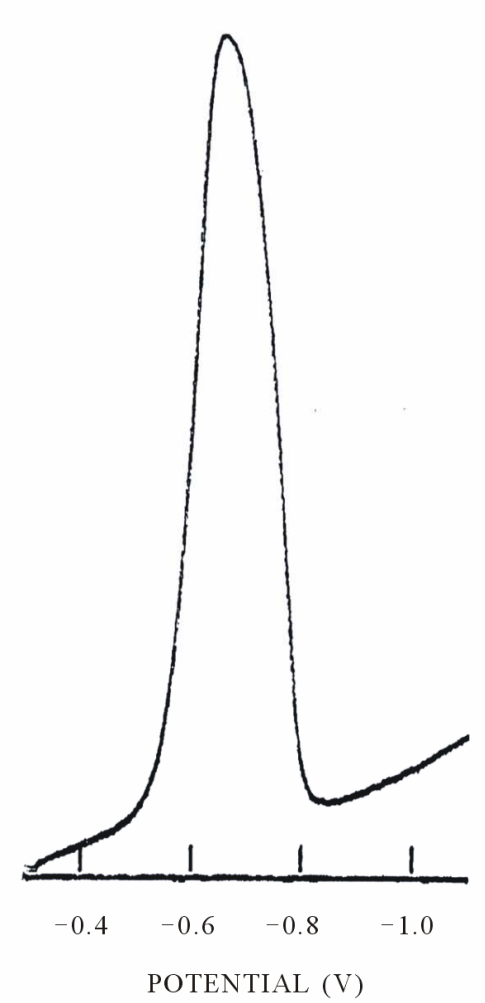

(b)

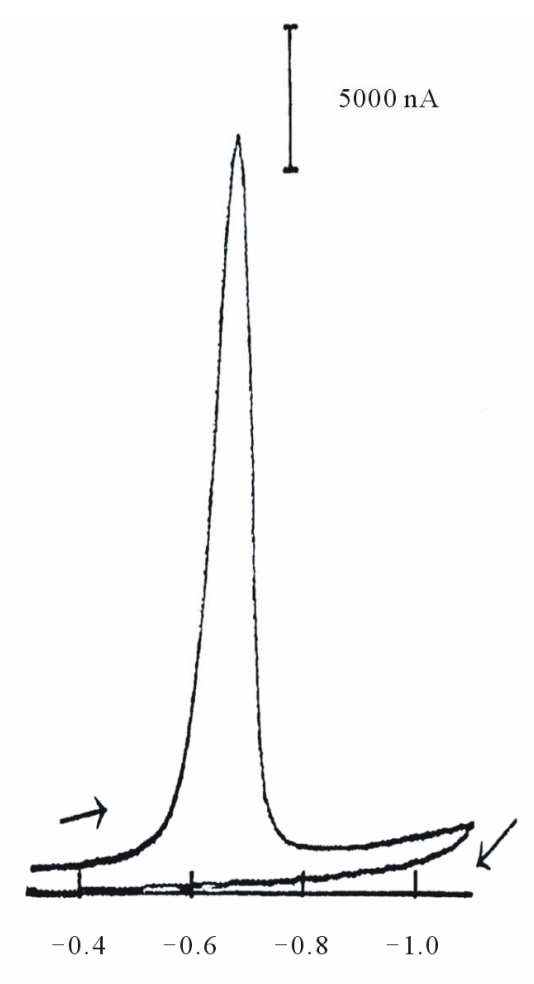

(c)

Figure 2. Differential-pulse (a), linear-scan (b) and linear-sweep adsorptive (c) voltammograms of 0.10 ppm zidovudine in $2.0 \times$ $10^{-3} \mathrm{~mol} \cdot \mathrm{L}^{-1} \mathrm{NaOH}$ (with $1 \% \mathrm{v} / \mathrm{v}$ of ethylic alcohol). Condition time, $60 \mathrm{~s}$ at $-0.90 \mathrm{~V}$; accumulation time, $90 \mathrm{~s}$ at $-0.30 \mathrm{~V}$ with stirring; amplitude pulse, $50 \mathrm{mV}(\mathrm{a})$; scan rate, $50(\mathrm{a})$ and $100(\mathrm{~b}, \mathrm{c}) \mathrm{mV} \cdot \mathrm{s}^{-1}$; thin-film mercury electrode $(5 \mathrm{~min}$ at $-0.9 \mathrm{~V})$. 


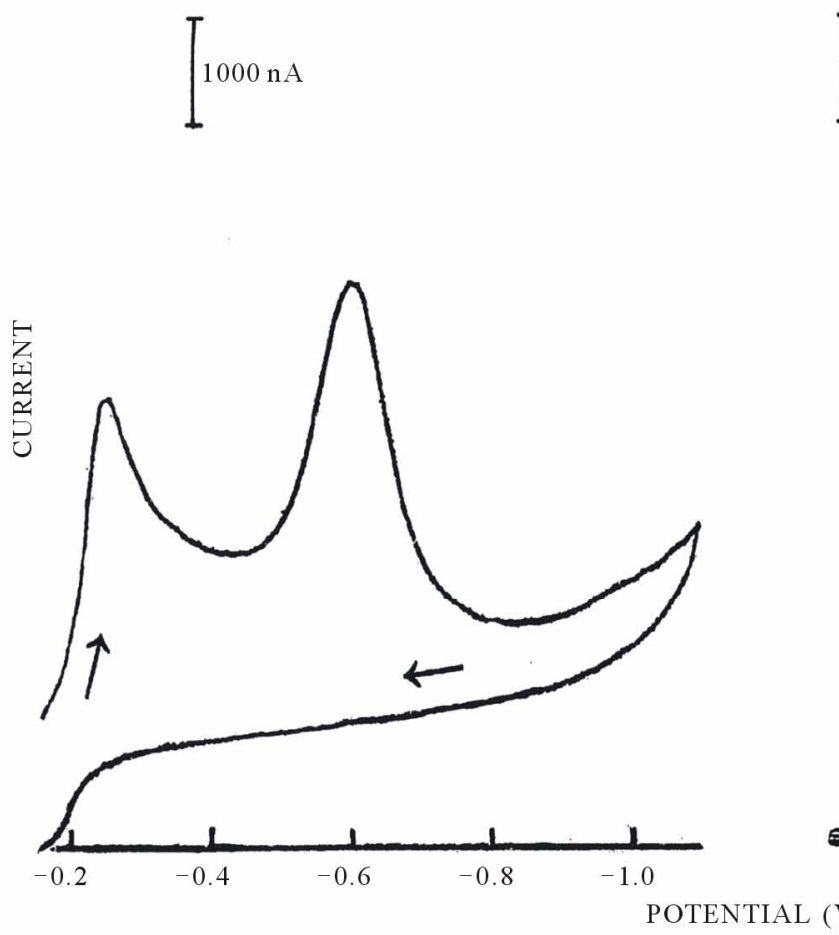

(a)

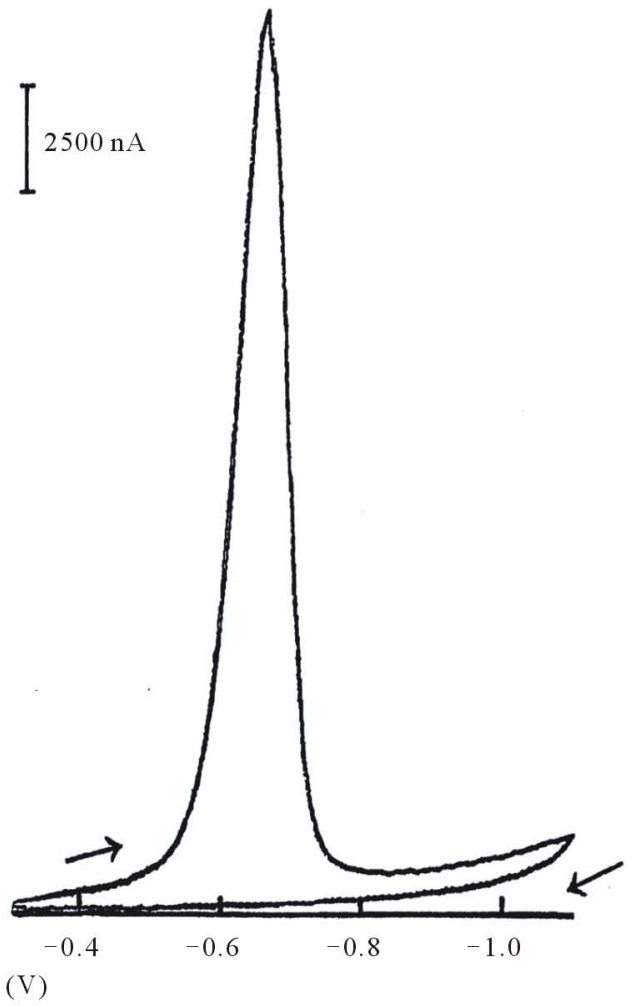

(b)

Figure 3. Linear-sweep adsorptive voltammogram of a $0.10 \mathrm{ppm}$ zidovudine solution in $2.0 \times 10^{-3} \mathrm{~mol} \cdot \mathrm{L}^{-1} \mathrm{NaOH}($ with $1 \% \mathrm{v} / \mathrm{v}$ of ethylic alcohol). Condition time, $60 \mathrm{~s}$ at $-0.90 \mathrm{~V}$; accumulation time, $60 \mathrm{~s}$ at -0.15 (a) and -0.30 (b) $\mathrm{V}$ with stirring; scan rate, $100 \mathrm{mV} \cdot \mathrm{s}^{-1}$; thin-film mercury electrode $(5 \mathrm{~min}$ at $-0.9 \mathrm{~V})$.

phosphate and $\mathrm{NaOH}$ solution, were determined to be suitable media for the adsorptive stripping measurement of zidovudine. The best results (with respect to signal enhancement and reproducibility) were obtained using the $\mathrm{NaOH}$ electrolyte. The alkaline medium was employed throughout this study. The adsorptive stripping signal of zidovudine depends on the sample $\mathrm{pH}$.

Figure 4 shows the dependence of the zidovudine peak current on the solution's $\mathrm{pH}$ (from 2 to 11 ). No response to zidovudine was observed in solutions more acidic than $\mathrm{pH}$ 6. Increasing the $\mathrm{pH}$ level from 6.5 to 11 resulted in rapid increase in the zidovudine peak current. However, the stability of the zidovudine peak in aqueous solutions decreased when the $\mathrm{pH}$ was above 11 . Because of this, a $\mathrm{pH}$ of approximately 11 was used to satisfy the sensitivity and stability requirements throughout the experiment.

Figure 5 shows a detailed study of the effect of the accumulation potential (from +0.05 to $-0.30 \mathrm{~V}$ ) on the stripping zidovudine voltammograms. Parameters like the potential peak $\left(E_{p}\right)$, the half-width $\left(b^{1 / 2}\right)$ and the current peak $\left(I_{p}\right)$ were also observed. The first zidovudine peak at approximately $0.28 \mathrm{~V}$ is closer than the other HIV drugs' peaks, which were previously analyzed as possible interferences to ziduvudine determination. The second peak, at $-0.68 \mathrm{~V}$, is in agreement with the peak observed in Figure 3(b), which shows a very welledfined peak with best half-width/ background resolution. The accumulation potential at $-0.30 \mathrm{~V}$ was then confirmed as ideal and used throughout this study.

Figure 6 shows a study of the effect of the scan rate at 10 (a) and $200 \mathrm{mV} \cdot \mathrm{s}^{-1}$ (b) on the zidovudine stripping voltammograms. With a scan rate of $200 \mathrm{mV} \cdot \mathrm{s}^{-1}$, the peak current for a $0.10 \mathrm{ppm}$ zidovudine solution was about 30.5 times larger than the corresponding peak obtained with $10 \mathrm{mV} \cdot \mathrm{s}^{-1}$ response. However, this gain in sensitivevity is accompanied by broadening peaks. The peak current $\left(I_{p}\right)$ for the surface-adsorbed zidovudine is directly proportional to the scan rate $(v)$. A plot of $I_{p}$ vs $v$ was linear (correlation coefficient, 0.998), with a slope of 235.3 , over the $10-100 \mathrm{mV} \cdot \mathrm{s}^{-1}$ range. Overall, a scan rate of $100 \mathrm{mV} \cdot \mathrm{s}^{-1}$ would be the best solution when considering the sensitivity, resolution and speed requirements.

Figure 7 shows the dependence of the linear cyclic current peak along with the pre-concentration time. The peak increases linearly with time and then levels off. Such time-dependent profiles represent the corresponding 


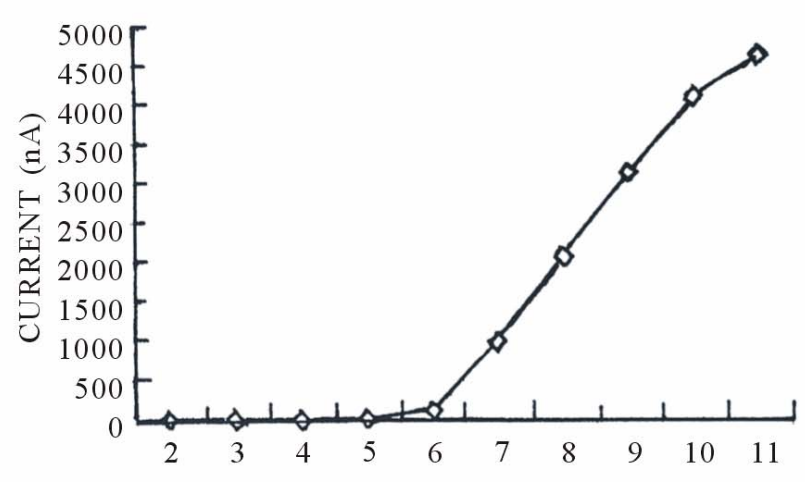

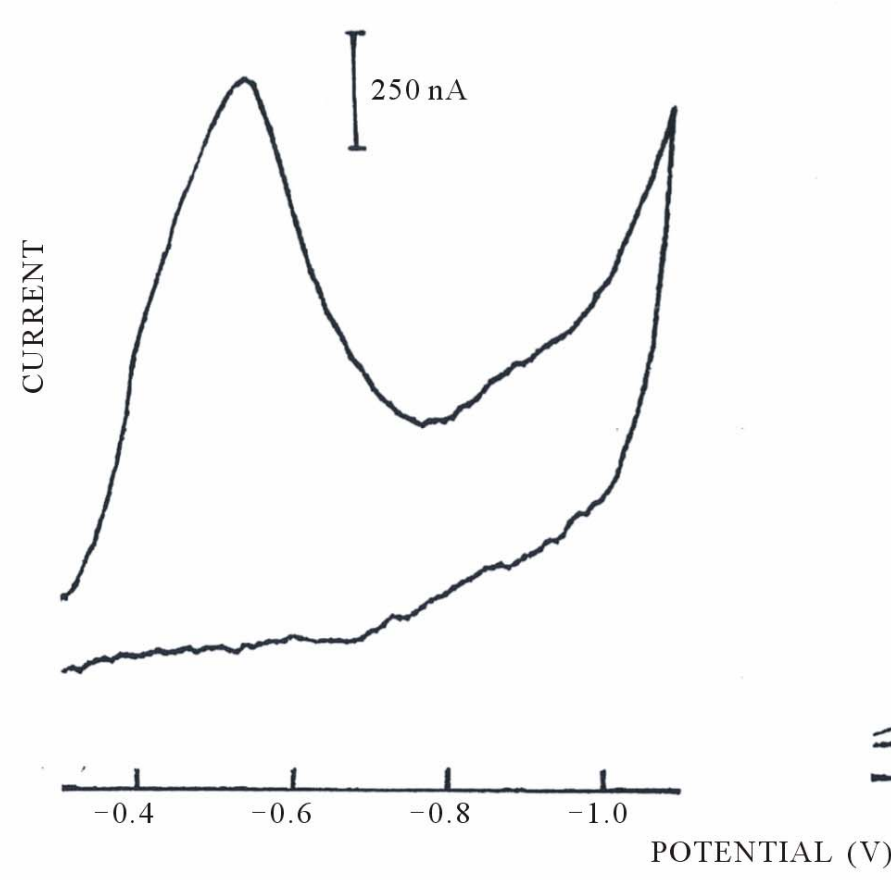

(a)

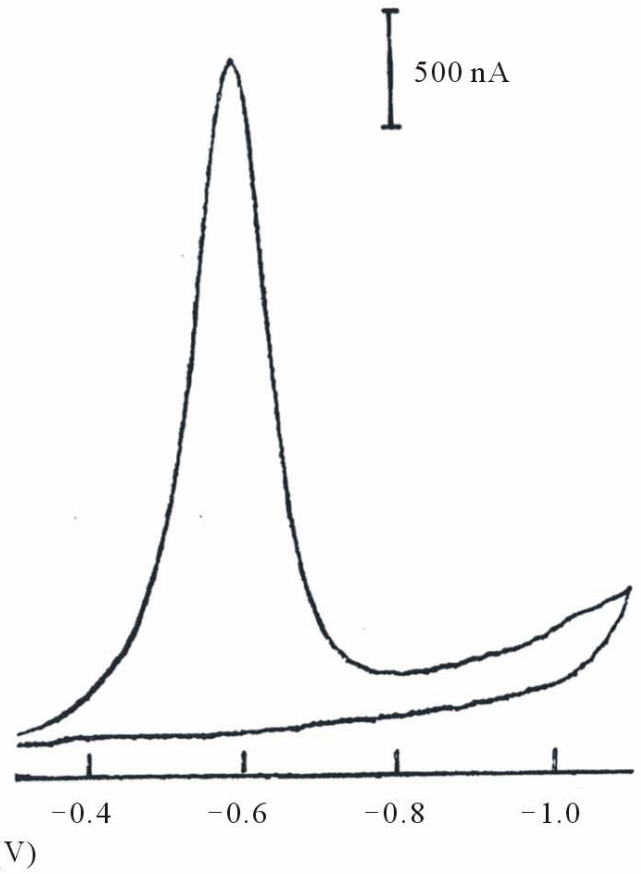

(b)

Figure 4. Effect of pH (A-7; B-11) on the linear-sweep adsorptive stripping voltammograms of 0.05 ppm zidovudine. Conditions: time, $60 \mathrm{~s}$ at $-0.90 \mathrm{~V}$; accumulation time, $90 \mathrm{~s}$ at $-0.30 \mathrm{~V}$; scan rate, $100 \mathrm{mV} \cdot \mathrm{s}^{-1}$; equilibrium time, $30 \mathrm{~s}$; thin-film mercury electrode $(5 \mathrm{~min}$ at $-0.9 \mathrm{~V})$. Also shown is the resulting current peak versus $\mathrm{pH}$ plot.

absorption isotherms since the peak current depends on the amount adsorbed. With $90 \mathrm{~s}$ of pre-concentration, the peak current for a $0.10 \mathrm{ppm}$ zidovudine solution was about 13.3 times larger than the corresponding peak obtained with a direct $(0 \mathrm{~s})$ response. The resulting plot of peak current vs. accumulation time $(0-60 \mathrm{~s})$ is linear (slope $240.8 \mathrm{nA} \cdot \mathrm{s}^{-1}$ and correlation coefficient, 0.993).

\subsection{Quantitative Utility}

The effect of the pre-concentration associated with the adsorption process yields a significantly lower detection limit compared to the corresponding solution measurements. A detection limit of $0.67 \mathrm{ppb}\left(2.5 \times 10^{-9} \mathrm{~mol} \cdot \mathrm{L}^{-1}\right)$ was estimated from quantifying $0.01 \mathrm{ppm}$ after a 5 -min accumulation $(\mathrm{S} / \mathrm{N}=2)$. Thus, $6.7 \mathrm{ng}$ was detected in the $10 \mathrm{~mL}$ of solution used. The reproducibility was estimated by was taking ten successive measurements of a stirred $0.04 \mathrm{ppm}$ zidovudine solution (other conditions: supporting electrolyte, $2.0 \times 10^{-3} \mathrm{~mol} \cdot \mathrm{L}^{-1} \mathrm{NaOH}$ (with $1 \% \mathrm{v} / \mathrm{v}$ of ethylic alcohol); condition time, $60 \mathrm{~s}$ at $-0.9 \mathrm{~V}$; accumulation time, $90 \mathrm{~s}$ at $-0.3 \mathrm{~V}$; final potential, $-1.1 \mathrm{~V}$; scan rate, $100 \mathrm{mV} \cdot \mathrm{s}^{-1}$; equilibrium time, $30 \mathrm{~s}$ and thinfilm mercury electrode). The mean peak current was $5503 \mathrm{nA}$ with a range of 5407 - $5593 \mathrm{nA}$ and a relative standard deviation. The $E_{p}$ and the $b_{1 / 2}$ remained the same at $-0.68 \mathrm{~V}$ and $80 \mathrm{mV}$, respectively. Figure 8 displays voltammograms for increasing zidovudine concentration (A -0.02 and $\mathrm{B}-0.08 \mathrm{ppm}$ ) after $90 \mathrm{~s}$ of accumulation. Well-defined stripping peaks (at $-0.68 \mathrm{~V}$ ) were 


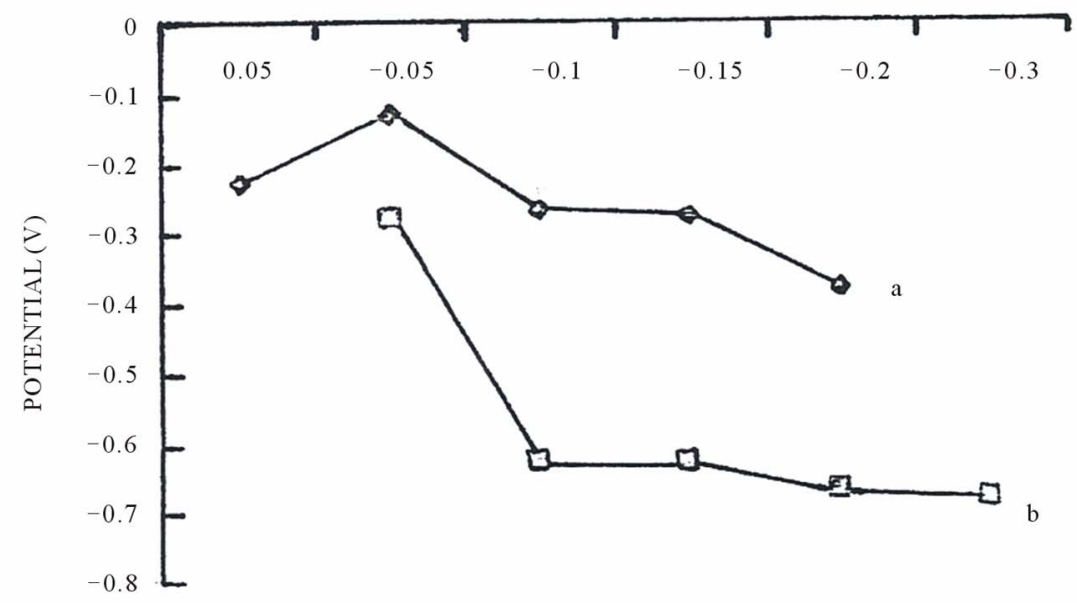

(A)

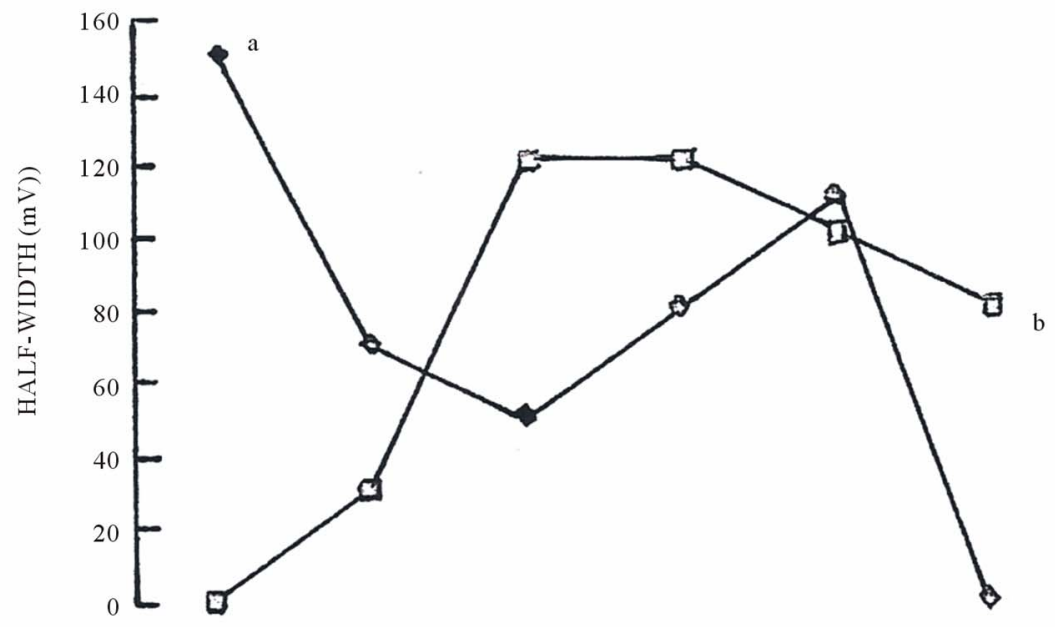

(B)

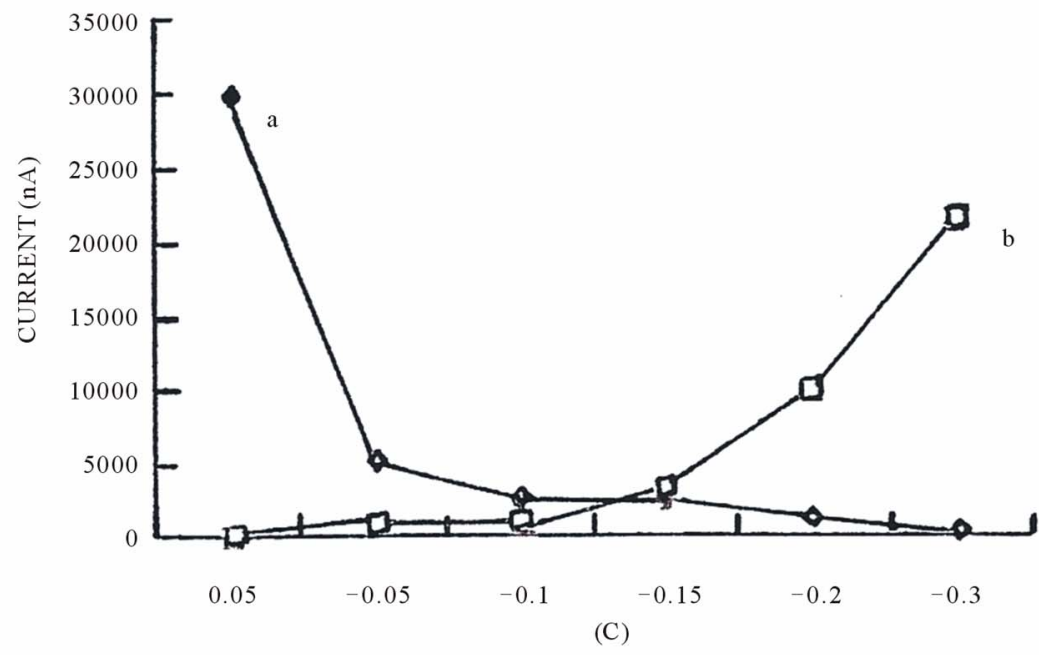

Figure 5. Effect of accumulation potential on the linear-sweep adsorptive stripping voltammograms of 0.10 ppm zidovudine solution in $2.0 \times 10^{-3} \cdot \mathrm{mol} \cdot \mathrm{L}^{-1} \mathrm{NaOH}$ (with $1 \% \mathrm{v} / \mathrm{v}$ of ethylic alcohol). Conditions: time, $60 \mathrm{~s}$ at $-0.90 \mathrm{~V}$; accumulation time, 60 ; scan rate, $100 \mathrm{mV} \cdot \mathrm{s}^{-1}$; equilibrium time, $30 \mathrm{~s}$; thin-film mercury electrode $(5 \mathrm{~min}$ at $-0.9 \mathrm{~V})$. (A) Accumulation potential versus potential zidovudine peak, (B) versus half-width of zidovudine peak and (C) versus current zidovudine peak. (a) Zidovudine first peak and (b) second zidovudine peak. 

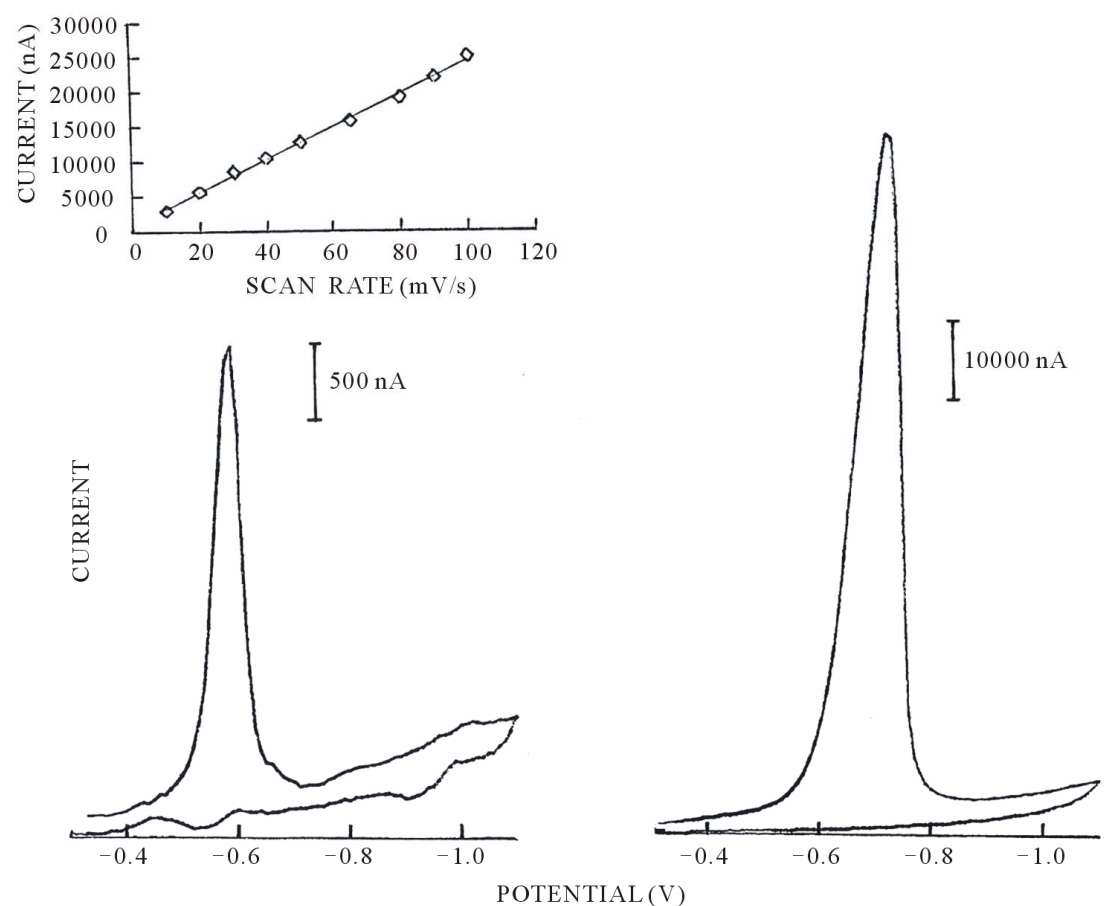

(a)

(b)

Figure 6. Effect of scan rate on the linear-sweep voltammograms of $0.10 \mathrm{ppm}$ zidovudine in $2.0 \times 10^{-3} \mathrm{~mol} \cdot \mathrm{L}^{-1} \mathrm{NaOH}(\mathrm{with} 1 \%$ $\mathrm{v} / \mathrm{v}$ of ethylic alcohol). Accumulation time, $90 \mathrm{~s}$ at $-0.30 \mathrm{~V}$. Final potential, $-1.1 \mathrm{~V}$. The (a) and (b) curves are relative to scan rate of 10 and $200 \mathrm{mV} \cdot \mathrm{s}^{-1}$, respectively. Conditions: time, $60 \mathrm{~s}$ at $-0.90 \mathrm{~V}$; equilibrium time, $30 \mathrm{~s}$; thin-film mercury electrode (5 min at $-0.9 \mathrm{~V}$ ). Also shown is the resulting current peak versus scan rate plot.
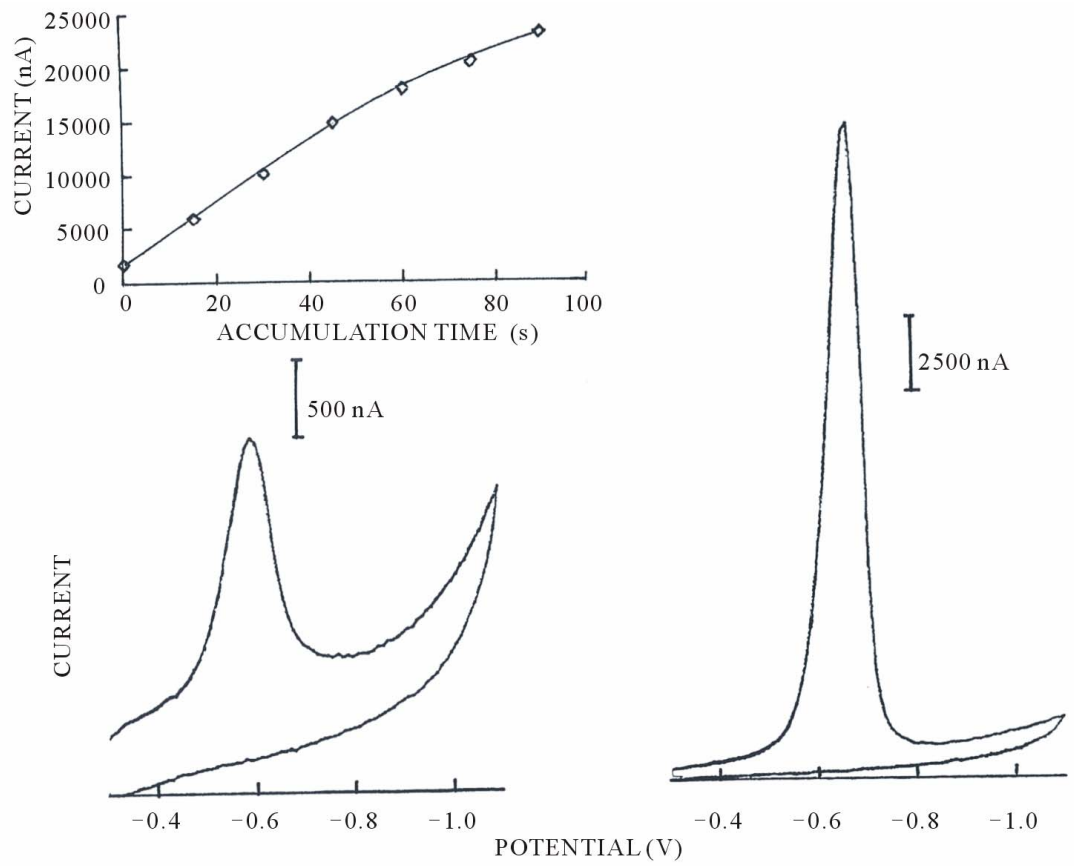

(a)

(b)

Figure 7. Effects of accumulation time at $-0.30 \mathrm{~V}$ on the linear-sweep adsorptive stripping voltammograms of $0.10 \mathrm{ppm}$ of zidovudine in $2.0 \times 10^{-3} \mathrm{~mol} \cdot \mathrm{L}^{-1} \mathrm{NaOH}$ (with $1 \% \mathrm{v} / \mathrm{v}$ of ethylic alcohol). The (a) and (b) curves are relative to accumulation times of 5 and $90 \mathrm{~s}$, respectively. Condition time, $60 \mathrm{~s}$ at $-0.90 \mathrm{~V}$; scan rate, $100 \mathrm{mV} \cdot \mathrm{s}^{-1}$, equilibrium time, $30 \mathrm{~s}$; thin-film mercury electrode $(5 \mathrm{~min}$ at $-0.9 \mathrm{~V})$. Also shown is the resulting current peak versus accumulation time plot. 


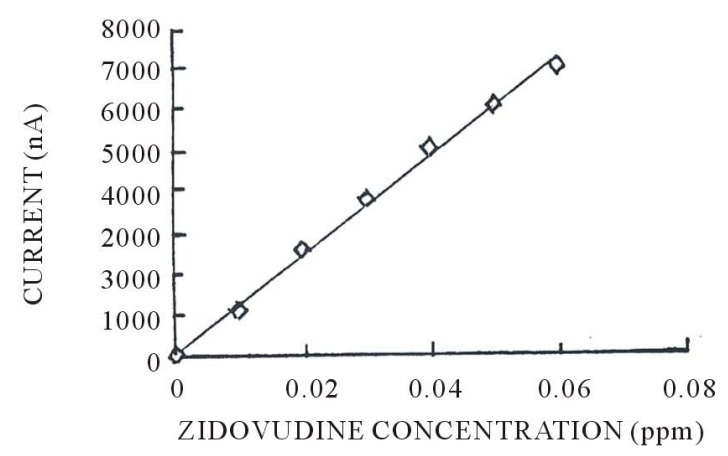

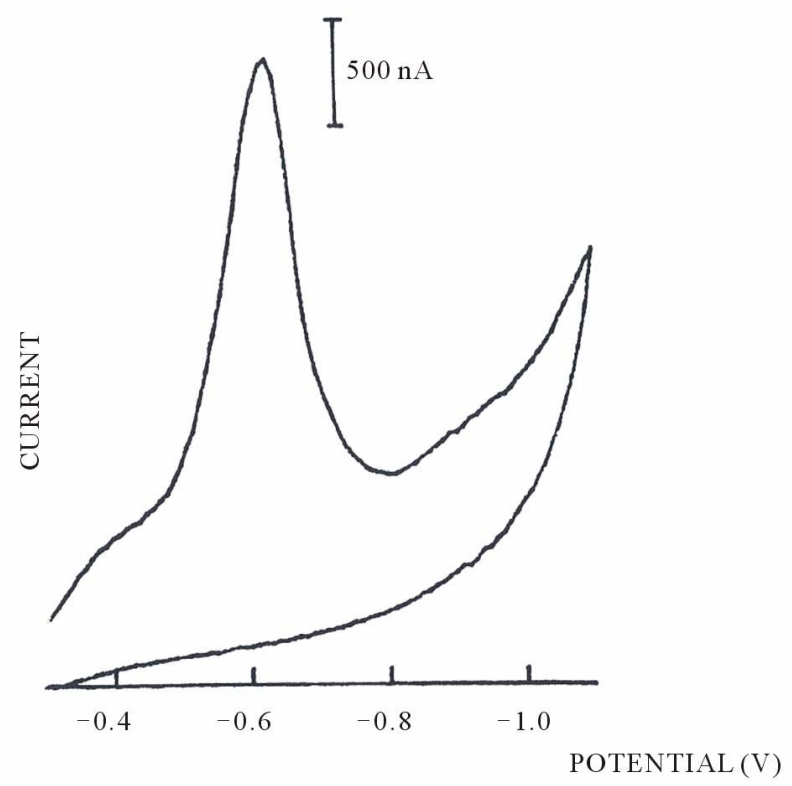

(a)

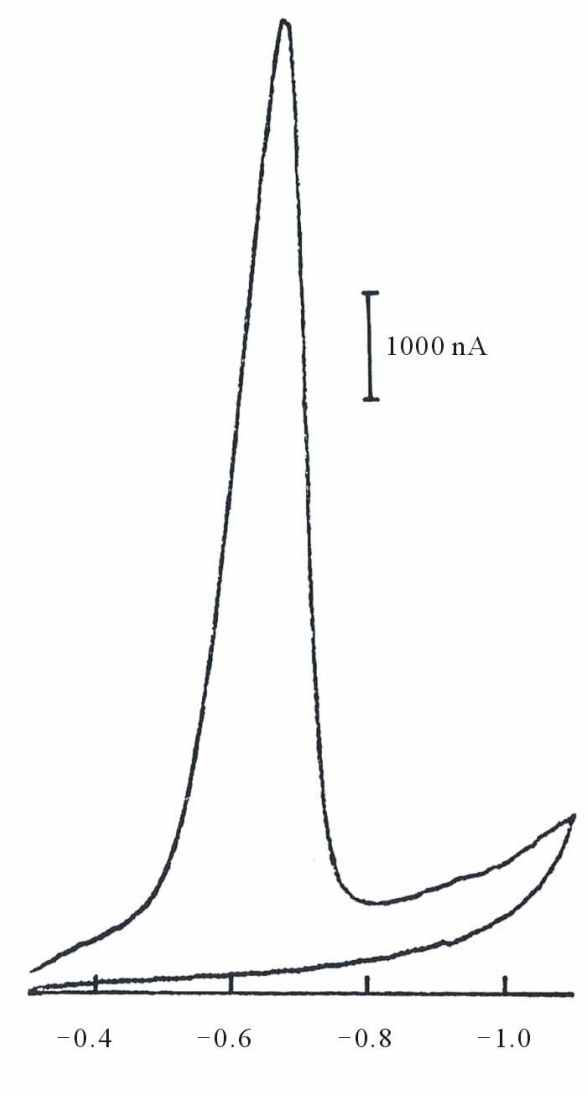

(b)

Figure 8. Linear-sweep adsorptive stripping voltammograms obtained after increasing the zidovudine concentration in a solution of $2.0 \times 10^{-3} \mathrm{~mol} \cdot \mathrm{L}^{-1} \mathrm{NaOH}($ with $1 \% \mathrm{v} / \mathrm{v}$ of ethylic alcohol). The (a) and (b) curves are relative to 0.02 and $0.08 \mathrm{ppm}$ of zidovudine concentration, respectively. Accumulation time, $90 \mathrm{~s}$ at $-0.30 \mathrm{~V}$. Condition time, $60 \mathrm{~s}$ at $-0.9 \mathrm{~V}$. Scan rate, 100 $\mathrm{mV} \cdot \mathrm{s}^{-1}$. Final potential at $-1.1 \mathrm{~V}$. Equilibrium time, $30 \mathrm{~s}$. Thin-film mercury electrode $(5 \mathrm{~min}$ at $-0.9 \mathrm{~V})$. Also shown is the resulting calibration curve plot.

observed between the 0.01 and the 0.06 zidovudine concentration ranges. The plot of peak current versus concentration that resulted is linear (slope $119014 \mathrm{nA} / \mathrm{ppm}$; correlation coefficient, 0.998). This linearity prevails as long as linear isotherm conditions (low surface coverage) continue to exist. Table 1 shows a summary of the optimized conditions for zidovudine determination by linear cyclic adsorptive stripping voltammetry at the mercury film electrode.

Practical applications of the linear-sweep adsorptive stripping analyses may be interfered with by the presence of metal ions and/or surface active compounds. With respect to the surface reaction, double layer changes or direct interactions deriving from these substances may inhibit or aid in the accumulation of the analyte. Measurements of $0.05 \mathrm{ppm}$ zidovudine (other conditions: supporting electrolyte, $2.0 \times 10^{-3} \mathrm{~mol} \cdot \mathrm{L}^{-1} \mathrm{NaOH}$ (with $1 \% \mathrm{v} / \mathrm{v}$ of ethylic alcohol); condition time, $60 \mathrm{~s}$ at $-0.9 \mathrm{~V}$; accumulation time, $90 \mathrm{~s}$ at $-0.30 \mathrm{~V}$; final potential, -1.1 $\mathrm{V}$; scan rate, $100 \mathrm{mV} \cdot \mathrm{s}^{-1}$; equilibrium time, $30 \mathrm{~s}$ and thin-film mercury electrode) were not affected by the addition of up to $0.03 \mathrm{ppm}$ of lead (II); up to $0.05 \mathrm{ppm}$ of cobalt (II); up to $0.06 \mathrm{ppm}$ of nickel (II) and up to 0.10 ppm of iron (III) or copper (II) or cadmium (II) or zinc (II). Preliminary studies were developed for the dete mination of zidovudine in the presence of other antiretroviral drugs for the treatment of human immunodeficiency virus (HIV): didanosine, acyclovir, nevirapine 
Table 1. Optimized conditions for zidovudine determination by linear cyclic adsorptive stripping voltammetry at the mercury film electrode.

\begin{tabular}{cc}
\hline Parameters & Optimized conditions \\
\hline Thin-film mercury electrode & 5 minutes at $-0.9 \mathrm{~V}$ \\
Zidovudine concentration range & $0.01-0.08 \mathrm{ppm}$ \\
Electrolyte & $2.0 \times 10^{-3} \mathrm{~mol} \cdot \mathrm{L}^{-1} \mathrm{NaOH}$ \\
Scan mode & $\mathrm{Linear}$ cyclic \\
Initial potential & $-0.3 \mathrm{~V}$ \\
Final potential & $-1.1 \mathrm{~V}$ \\
Scan rate & $100 \mathrm{mV} \cdot \mathrm{s}^{-1}$ \\
Condition potential & $-0.9 \mathrm{~V}$ \\
Condition time & $60 \mathrm{~seconds}$ \\
Accumulation potential & $-0.3 \mathrm{~V}$ \\
Accumulation time & $90 \mathrm{~seconds}$ \\
Equilibrium time & $30 \mathrm{~seconds}$ \\
\hline
\end{tabular}

and lamivudine. Measurements of $0.05 \mathrm{ppm}$ zidovudine (other conditions: supporting electrolyte, $2.0 \times 10^{-3} \mathrm{~mol} \cdot \mathrm{L}^{-1}$ $\mathrm{NaOH}$ (with $1 \% \mathrm{v} / \mathrm{v}$ of ethylic alcohol); condition time, $60 \mathrm{~s}$ at $-0.9 \mathrm{~V}$; accumulation time, $90 \mathrm{~s}$ at $-0.30 \mathrm{~V}$; final potential, $-1.1 \mathrm{~V}$; scan rate, $100 \mathrm{mV} \cdot \mathrm{s}^{-1}$; equilibrium time, $30 \mathrm{~s}$ and thin-film mercury electrode) were not affected by the addition of up to $0.06 \mathrm{ppm}$ of lamivudine or up to $0.10 \mathrm{ppm}$ of acyclovir, nevirapine, didanosine or efavirenz.

Figure 9 illustrates the method's suitability for the determination of zidovudine through linear-sweep adsorptive stripping voltammetry in a synthetic sample containing several antiretroviral drugs (efavirenz, nevirapine, didanosine, lamivudine, zidovudine and acyclovir; all with $2.0 \mathrm{ppm}$ of concentration). Four successive standard additions to the sample resulted in well-shaped adsorptive stripping peaks. The zidovudine peak in the original sample (curve A) can, therefore, be quantified

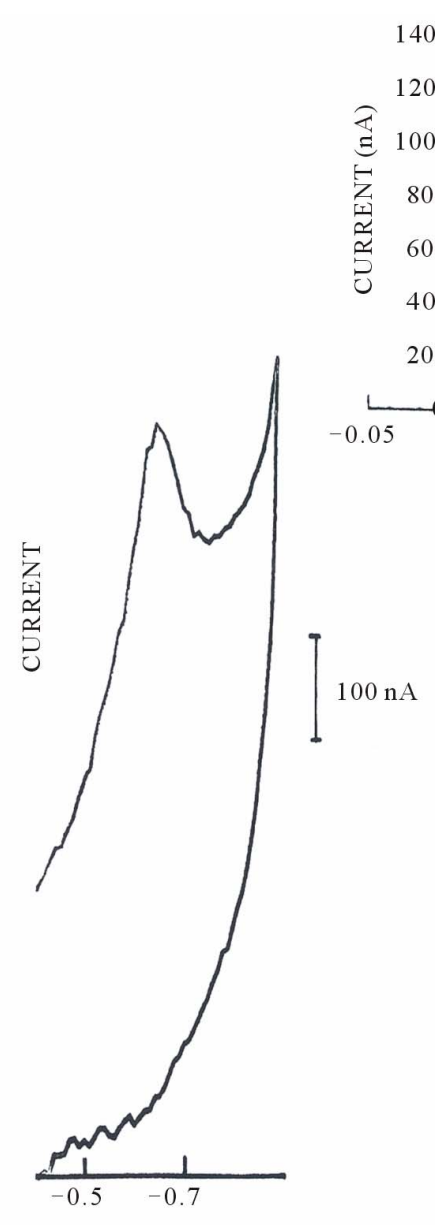

(a)
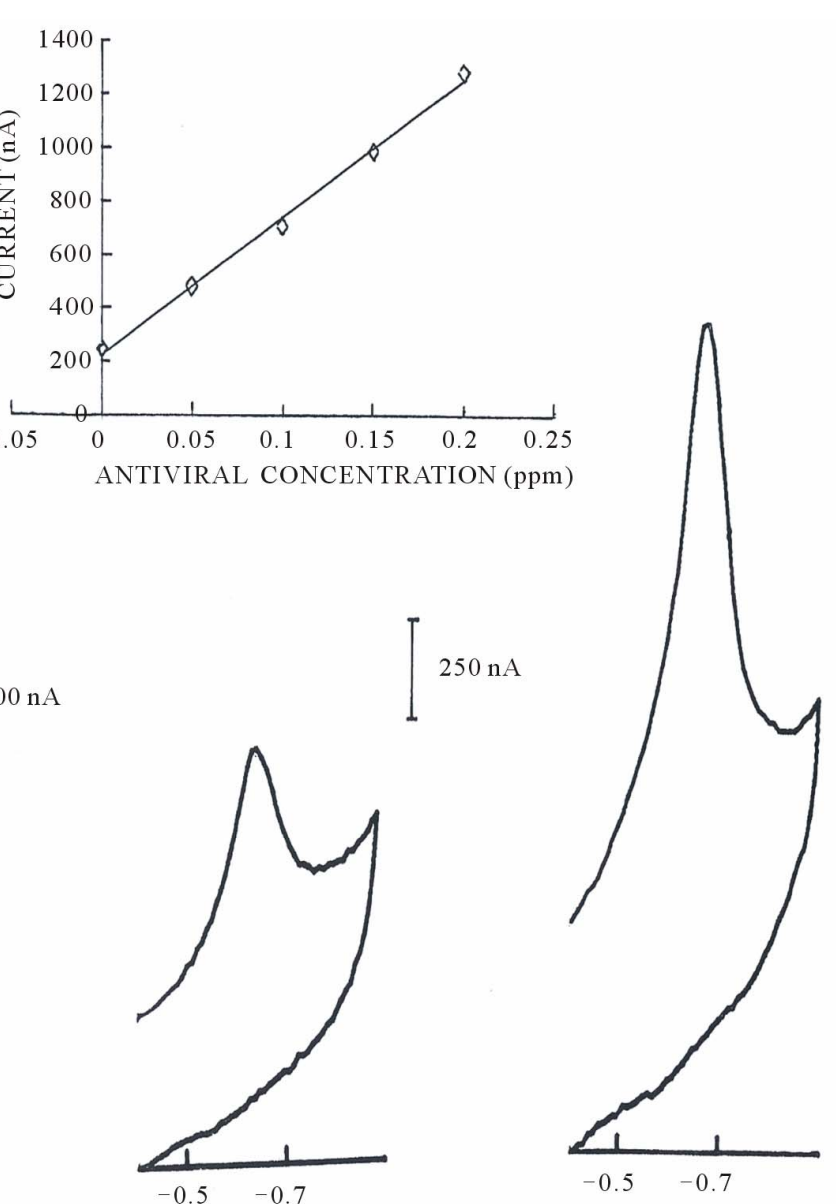

(c)

Figure 9. Illustration of zidovudine determination in a synthetic sample contain several antiretroviral drugs (efavirenz, nevirapine, didanosine, lamivudine, zidovudine and acyclovir; all with $2 \mathrm{ppm}$ of concentration) by linear-sweep adsorptive stripping voltammetry. Supporting electrolyte, $10 \mathrm{~mL}$ of $2.0 \times 10^{-3} \mathrm{~mol} \cdot \mathrm{L}^{-1} \mathrm{NaOH}$. (a) addition of $150 \mu \mathrm{L}$ of synthetic sample; (b) $(0.05 \mathrm{ppm})$ and $(\mathrm{c})(0.20 \mathrm{ppm})$ addition of standard zidovudine. Condition time, $60 \mathrm{~s}$ at $-0.9 \mathrm{~V}$. Accumulation time, $90 \mathrm{~s}$ at -0.40 $\mathrm{V}$. Potential final, $-0.9 \mathrm{~V}$. Scan rate, $100 \mathrm{mV} \cdot \mathrm{s}^{-1}$. Equilibrium time, $30 \mathrm{~s}$. Thin-film mercury electrode $(5 \mathrm{~min}$ at $-0.9 \mathrm{~V})$. 
based on the resulting standard addition plot (also show in Figure 9). Because of the inherent sensitivity of this method, short (90 s) accumulation times should be used. Five consecutive analyses of the sample yielded an average value of $2.7 \mathrm{ppm}$ with a standard deviation of 0.5 ppm, in "relative" agreement with the zidovudine value $(2.0 \mathrm{ppm})$. Preliminary studies were also developed for the determination of zidovudine in the presence of ssDNA and ATP. The current measurements of $0.05 \mathrm{ppm}$ of zidovudine (other conditions: supporting electrolyte, $2.0 \times 10^{-3} \mathrm{~mol} \cdot \mathrm{L}^{-1} \mathrm{NaOH}$ (with $1 \% \mathrm{v} / \mathrm{v}$ of ethylic alcohol); condition time, $60 \mathrm{~s}$ at $-0.9 \mathrm{~V}$; accumulation time, $90 \mathrm{~s}$ at $-0.30 \mathrm{~V}$; final potential, $-1.1 \mathrm{~V}$; scan rate, 100 $\mathrm{mV} \cdot \mathrm{s}^{-1}$; equilibrium time, $30 \mathrm{~s}$ and thin-film mercury electrode) were not affected by the addition of up to 0.10 ppm of ATP or 0.06 ppm of ssDNA.

The Figure 10 shows the linear cyclic adsorptive stripping voltammograms of $0.05 \mathrm{ppm}$ zidovudine in the presence of copper II ions and ssDNA (0.10 ppm) using an accumulation time of $90 \mathrm{~s}$ at -0.15 (A) and -0.30 (B) $\mathrm{V}$ (other conditions: supporting electrolyte, $2.0 \times 10^{-3}$ $\mathrm{mol} \cdot \mathrm{L}^{-1} \mathrm{NaOH}$ (with $1 \% \mathrm{v} / \mathrm{v}$ of ethylic alcohol); condition time, $60 \mathrm{~s}$ at $-0.9 \mathrm{~V}$; final potential, $-1.2 \mathrm{~V}$; scan rate, $100 \mathrm{mV} \cdot \mathrm{s}^{-1}$; equilibrium time, $30 \mathrm{~s}$ and thin-film mercury electrode). When the accumulation potential was applied to the $-0.15 \mathrm{~V}$ (prior to the scan) the zidovudine peak appears at $-0.35 \mathrm{~V}$ and the ssDNA peak at $-0.78 \mathrm{~V}$, but at $-0.30 \mathrm{~V}$ the ziduvudine peak appears at $-0.63 \mathrm{~V}$ and the ssDNA at $-0.79 \mathrm{~V}$. Without the present copper II ions, the ssDNA current peak does not appear efficiently. The zidovudine and ssDNA current peaks increase with higher accumulation times. A small peak of the copper (II) ion was also observed in the anodic scan at $-0.40 \mathrm{~V}$.

\section{Conclusions}

This paper has thoroughly described an effective means for the determination of trace levels of zidovudine. The use of the simple and diluted alkaline electrolytes provided a sensitive and selective adsorptive stripping voltammetric method for zidovudine determination. This approach is rapid, yields a high sensitivity, and is largely unaffected by a large number of commonly presented antiretroviral drugs for the treatment of human immunodeficiency virus (HIV), such as didanosine, acyclovir, nevirapine and lamivudine. The zidovudine peak is separated by $0.43 \mathrm{~V}$ with the ssDNA stripping peaks. In particular, this approach offers similar efficiency in comparison to electrochemistry [24] and chromatographic methods. Additionally, further studies using diluted alkaline solution as the supporting electrolyte and film mercury electrode modified in situ by metallic ions can be

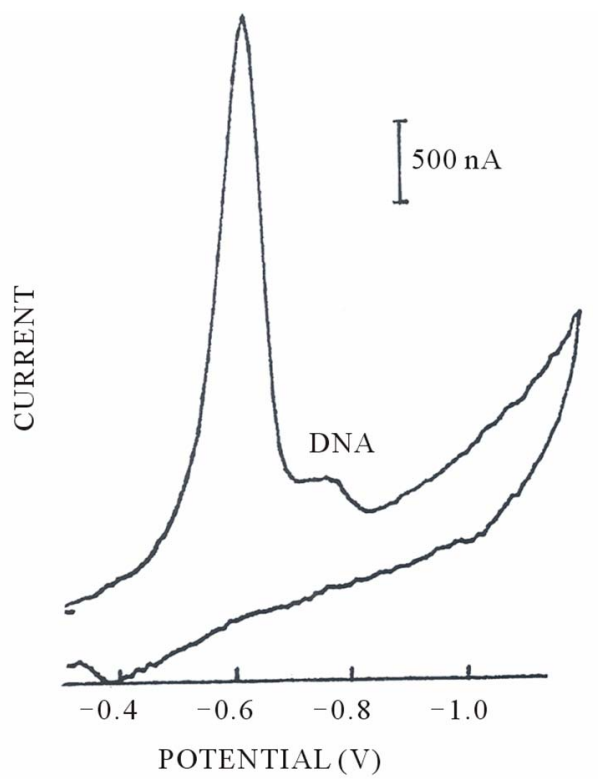

(a)

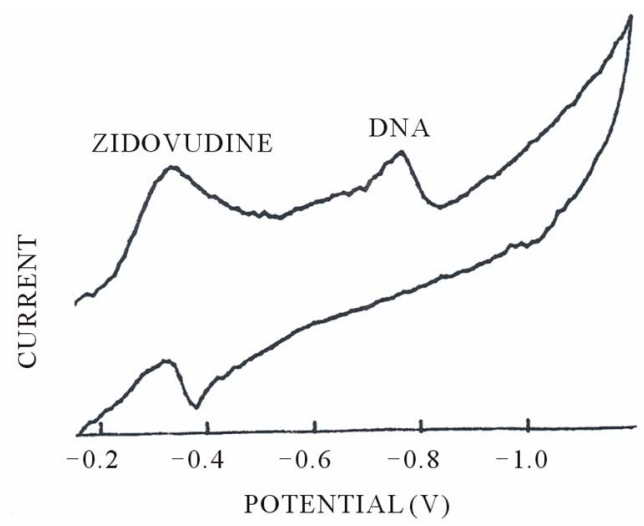

(b)

Figure 10. Linear-sweep adsorptive stripping voltammogram of zidovudine $(0.05 \mathrm{ppm})$ in the presence of copper II ions and DNA $(0.10 \mathrm{ppm})$ in a solution of $2.0 \times 10^{-3} \mathrm{~mol} \cdot \mathrm{L}^{-1}$ $\mathrm{NaOH}$ (with $1 \% \mathrm{v} / \mathrm{v}$ of ethylic alcohol). Accumulation time, $90 \mathrm{~s}$ at -0.15 (a) and -0.30 (b) V. Condition time, $60 \mathrm{~s}$ at -0.9 $\mathrm{V}$. Scan rate, $100 \mathrm{mV} \cdot \mathrm{s}^{-1}$. Final potential at $-1.2 \mathrm{~V}$. Equilibrium time, $30 \mathrm{~s}$. Thin-film mercury electrode $(5 \mathrm{~min}$ at -0.9 V).

used to detect other drugs and DNA-intercalating dyes, as well as amino-acids, peptides and protein determinations.

\section{Acknowledgements}

The authors gratefully acknowledge the CAPES-Brazil and MES-Cuba for their support of this work. In addition, we thank Dr. Katia Cristina Leandro of Fundação Oswaldo Cruz for generously supplying the sample of zidovudine. 


\section{References}

[1] J. P. Horwitz, J. Chua, and M. Noel, "Nucleosides. 5. Monomesylates of 1-(2]-Deoxy-Beta-D-Lyxofuranosyl) Thymine," Journal of Organic Chemistry, Vol. 29, No. 7, 1964, pp. 2076-2078. doi:10.1021/jo01030a546

[2] W. Ostertag, G. Roesler, C. J. Krieg, J. Kind, T. Cole, T. Crozier, G. Gaedicke, G. Steinheider, N. Kluge and S. Dube, "Induction of Endogenous Virus and of Thymidine Kinase by Bromodeoxyuridine in Cell-Cultures Transformed by Friend Virus," Proceedings of the National Academy of Sciences of the United States of America, Vol. 71, No. 12, 1974, pp. 4980-4985. doi:10.1073/pnas.71.12.4980

[3] H. Mitsuya, K. J. Weinhold, P. A. Furman, M. H. STCLair, S. N. Lehrman, R. C. Gallo, D. Bolognesi, D. W. Barry and S. Broder, '3'-Azido-3'-Deoxythymidine (BW A509U): An Antiviral Agent That Inhibits the Infectivity and Cytopathic Effect of Human Lymphotropic-T virus type-III Lymphadenopathy-Associated Virus In Vitro," Proceedings of the National Academy of Sciences of the United States of America, Vol. 82, No. 20, 1985, pp. 7096-7100.

[4] R. P. Quinn, B. Orban and S. Tadepalli, "Radioimmunoassay For Retrovir, An Anti-Human Immunodeficiency Virus Drug," Journal of Immunoassay, Vol. 10, No. 2-3, 1989, pp. 177-189. doi:10.1080/01971528908053235

[5] H. Mitsuya, R. Yarchoan, S. Hayashi and S. Broder, "Antiviral Therapy against HIV-Infection," Journal of the American Academy of Dermatology, Vol. 22, No. 6, 1990, pp. 1282-1294. doi:10.1016/0190-9622(90)70175-H

[6] S. D. Young, S. F. Britcher, L. O. Tran, L. S. Payne, W. C. Lumma, T. A. Lyle, J. R. Huff, P. S. Anderson, D. B. Olsen, S. S. Carroll, D. J. Pettibone, J. A. Obrien, R. G. Ball, S. K. Balani, J. H. Lin, I. W. Chen, W. A. Schleif, V. V. Sardana, W. J. Long, V. W. Byrnes, and E. A. L. Emini, “743,726 (DMP-266): A Novel, Highly Potent Nonnucleoside Inhibitor of the Human-Immunodeficiency-Virus Type-1 Reverse-Transcriptase," Antimicrobial Agents and Chemotherapy, Vol. 39, No. 12, 1995, pp. 2602-2605.

[7] G. J. Veal and D. J. Back, "Metabolism of Zidovudine," General Pharmacology, Vol. 26, No. 7, 1995, pp. 14691475. doi:10.1016/0306-3623(95)00047-X

[8] M. Gotte, X. G. Li and M. A. Wainberg, "HIV-1 Reverse Transcription: A Brief Overview Focused on StrucTure-Function Relationships among Molecules Involved in Initiation of the Reaction," Archives of Biochemistry and Biophysics, Vol. 365, No. 2, 1999, pp. 199-210. doi:10.1006/abbi.1999.1209

[9] O. Foldes, P. Uherova and V. Mayer, "Plasma-Levels of the Anti-HIV 3'-Azido-2', 3'-Dideoxythymidine (AZT) Determination by RIA and HPLC," Acta Virologica, Vol. 37, No. 2-3, 1993, pp. 156-164.

[10] T. Nadal, J. Ortuno and J. A. Pascual, "Rapid and sensitive determination of zidovudine and zidovudine glucuronide in human plasma by ion-pair high-perform- ance liquid chromatography," Journal of Chromatography A, Vol. 721, No. 1, 1996, pp. 127-137.
[11] J. Bloom, J. Ortiz and J. F. Rodriguez, "Azido-Thymidine Triphosphate Determination Using Micellar Electrokinetic Capillary Chromatography," Cellular and Molecular Biology, Vol. 43, No. 7, 1997, pp. 1051-1055.

[12] X. L. Tan and F. D. Boudinot, "Simultaneous Determination of Zidovudine and Its Monophosphate in Mouse Plasma and Peripheral Red Blood Cells by High-Performance Liquid Chromatography," Journal of Chromatography B-Analytical Technologies in the Biomedical and Life Sciences, Vol. 740, No. 2, 2000, pp. 281-287. doi:10.1016/S0378-4347(00)00109-2

[13] S. D. Brown, C. A. White and M. G. Bartlett, "HPLC Determination of Acyclovir and Zidovudine IN Maternal Plasma, Amniotic Fluid, Fetal, and Placental Tissues Using Ultra-Violet Detection," Journal of Liquid Chromatography \& Related Technologies, Vol. 25, No. 18, 2002, pp. 2857-2871. doi:10.1081/JLC-120014955

[14] A. Dunge, N. Sharda, B. Singh and S. Singh, "Validated Specific HPLC Method for Determination of Zidovudine during Stability Studies," Journal of Pharmaceutical and Biomedical Analysis, Vol. 37, No. 5, 2005, pp. 11091114. doi:10.1016/j.jpba.2004.09.013

[15] M. A. Quevedo, S. A. Teijeiro and M. C. Brinon, "Quantitative Plasma Determination of a Novel Antiretroviral Derivative of Zidovudine by Solid-Phase Extraction and High-Performance Liquid Chromatography," Analytical and Bioanalytical Chemistry, Vol. 385, No. 2, 2006, pp. 377-384. doi:10.1007/s00216-006-0404-7

[16] G. G. Granich, M. R. Eveland and D. J. Krogstad, "Fluorescence Polarization Immunoassay for Zidovudine," Antimicrobial Agents and Chemotherapy, Vol. 33, No. 8, 1989, pp. 1275-1279.

[17] R. I. Stefan and R. G. Bokretsion, "Diamond Paste Based Immunosensor for the Determination of Azido-Thymidine," Journal of Immunoassay \& Immunochemistry, Vol. 24, No. 3, 2003, pp. 319-324. doi:10.1081/IAS-120022941

[18] M. A. Raviolo, J. M. Sanchez, M. C. Brinon and M. A. Perillo, "Determination of Liposome Permeability of Ionizable Carbamates of Zidovudine by Steady State Fluo- rescence Spectroscopy," Colloids and Surfaces B-Bio- interfaces, Vol. 61, No. 2, 2008, pp. 188-198. doi:10.1016/j.colsurfb.2007.08.004

[19] G. C. Barone, H. B. Halsall and W. R. Heineman, "Electrochemistry of Azidothymidine," Analytica Chimica Acta, Vol. 248, No. 2, 1991, pp. 399-407. doi:10.1016/S0003-2670(00)84657-7

[20] G. C. Barone, A. J. Pesce, H. B. Halsall and W. R. Heineman "Electrochemical Determination of AzidoThymidine in Human Whole-Blood," Analytical Biochemistry, Vol. 198, No. 1, 1991, pp. 6-9. doi:10.1016/0003-2697(91)90497-H

[21] L. Trnkova, R. Kizek and J. Vacek, "Square Wave and Elimination Voltammetric Analysis of Azidothymidine in the Presence of Oligonucleotides and Chromosomal DNA," Bioelectrochemistry, Vol. 63, No. 1-2, 2004, pp. 31-36. doi:10.1016/j.bioelechem.2003.10.012

[22] J. Vacek, Z. Andrysik, L. Trnkova and R. Kizek, "Deter- 
mination of Azidothymidine: An Antiproliferative and Virostatic Drug by Square-Wave Voltammetry," Electroanalysis, Vol. 16, No. 3, 2004, pp. 224-230. doi:10.1002/elan.200302787

[23] K. Peckova, T. Navratil, B. Yosypchuk, J. C. Moreira, K. C. Leandro and J. Barek, "Voltammetric Determination of Azidothymidine Using Silver Solid Amalgam Electrodes," Electroanalysis, Vol. 21, No. 15, 2009, pp. 17501757. doi:10.1002/elan.200904660

[24] K. C. Leandro, J. C. Moreira and P. A. M. Farias "Determination of Zidovudine in Pharmaceuticals by Dif- ferential Pulse Voltammetry," Analytical Letters, Vol. 43, No. 12, 2010, pp. 1951-1957. doi:10.1080/00032711003687021

[25] P. A. M. Farias, A. de L. R. Wagener and A. A. Castro, "Adsorptive Voltammetric Behavior of Adenine in Presence of Guanine and Some Trace Elements at the Static Mercury Drop Electrode," Analytical Letters, Vol. 34, No.
12, 2001, pp. 2125-2140. doi:10.1081/AL-100106844

[26] P. A. M. Farias, A. de L. R. Wagener and A. A. Castro, "Adsorptive Voltammetric Behavior of Thymine in Presence of Guanine at the Static Mercury Drop Electrode," Analytical Letters, Vol. 34, No. 8, 2001, pp. 12951310. doi:10.1081/AL-100104154

[27] P. A. M. Farias, A. D. L. R. Wagener, A. A. Junqueira and A. A. Castro "Adsorptive Stripping Voltammetric Behavior of Adenosine Triphosphate (ATP) in Presence of Copper at the Mercury Film Electrode," Analytical Letters, Vol. 40, No. 9, 2007, pp. 1779-1790. doi:10.1080/00032710701384717

[28] P. A. M. Farias, A. A. Castro, A. D. R. Wagener and A. A. Junqueira, "DNA Determination in the Presence of Copper in Diluted Alkaline Electrolyte by Adsorptive Stripping Voltammetry at the Mercury Film Electrode," Electroanalysis, Vol. 19, No. 11, 2007, pp. 1207-1212. doi:10.1002/elan.200703845 